\title{
Comparison of arthropod communities between high and low input maize farms in Mexico
}

\author{
E. del-Val ${ }^{1 *} \mathbb{D}$, E. Ramírez ${ }^{1}$ and M. Astier ${ }^{2}$
}

\begin{abstract}
Background: Animal communities are vulnerable to agricultural practices. Intensive farming considerably reduces overall arthropod diversity, but not necessarily pest abundance. Natural control of herbivores in agroecosystems is accomplished by predators and parasitoids, but in intensified agricultural regimes, the chemical control used to reduce pest abundances also affects pests' natural enemies. To achieve more sustainable agriculture, there is a need to better understand the susceptibility of predators to conventional management.

Methods: In order to quantify the arthropod diversity associated with different schemes of agricultural management of maize, we evaluated agricultural fields under two contrasting management regimens in Michoacán, México during the spring-summer cycle of 2011. Arthropod communities were evaluated in plots with conventional high-input versus low-input agriculture in two sites-one rainfed and one with irrigation. The experimental units consisted of twelve 1 ha agricultural plots. To sample arthropods, we used 9 pitfall traps per agricultural plot.
\end{abstract}

Results: During the sampling period, we detected a total of 14,315 arthropods belonging to 12 Orders and 253 morphospecies. Arthropod community composition was significantly different between the sites, and in the rain-fed site, we also found differences between management practices. Predators, particularly ants, were more abundant in low-input sites. Herbivory levels were similar in all fields, with an average of $18 \%$ of leaf area lost per plant.

Conclusions: Our results suggest that conventional farming is not reducing herbivore abundances or damage inflicted to plants, but is affecting arthropod predators. We discuss repercussions for sustainable agriculture.

Keywords: Low-input agriculture, Conventional agriculture, Sustainability, Herbivores, Predators, Insects

\section{Introduction}

Arthropods were assumed to be resistant to anthropogenic changes and to have large populations worldwide. However, there is now strong documentation of arthropods' decline around the world. Dirzo et al. (2014) described a decrease in the abundance of certain insect

\footnotetext{
*Correspondence: ekdelval@iies.unam.mx

${ }^{1}$ Instituto de Investigaciones en Ecosistemas y Sustentabilidad, Universidad Nacional Autónoma de México, Antigua Carretera a Pátzcuaro No.8701. Col. Ex Hacienda de San José de la Huerta, Morelia, Michoacán C.P. 58190, Mexico

Full list of author information is available at the end of the article
}

groups. More recently, Hallmann et al. (2017) reported a striking $75 \%$ decline in flying insects in natural areas of Germany, and in a global review, van Klink et al. (2020) documented a declining trend for terrestrial arthropods worldwide, highlighting a significant information gap from the tropics. Insect pollinator decline has received significant attention, given the decreased productivity of many agricultural crops as well as the expansion of colony collapse disorder in bees (Potts et al. 2010). Dung beetles, another important insect group related to productive systems, have also been declining (Numa et al. 2020). Insect predator and parasitoid communities' conservation status have not been evaluated, even though original author(s) and the source, provide a link to the Creative Commons licence, and indicate if changes were made. The images or other third party material in this article are included in the article's Creative Commons licence, unless indicated otherwise in a credit line to the material. If material is not included in the article's Creative Commons licence and your intended use is not permitted by statutory regulation or exceeds the permitted use, you will need to obtain permission directly from the copyright holder. To view a copy of this licence, visit http://creativecommons.org/licenses/by/4.0/. The Creative Commons Public Domain Dedication waiver (http://creativeco mmons.org/publicdomain/zero/1.0/) applies to the data made available in this article, unless otherwise stated in a credit line to the data. 
they are crucial for biocontrol in agriculture and forestry (Desneux et al., 2007). On the other hand some herbivorous species (aphids, caterpillars and grasshoppers) with generalist habits that behave as pests in agricultural and forestry systems are increasing in abundance (Lehmann et al. 2000).

Since the green revolution, there has been a dramatic increase in the use of external inputs for agriculture (FAO 2003). Fertilizers, herbicides and pesticides in particular are used without considerations for health or environmental issues or for the particularities of each field (Akanksha et al. 2020). Therefore, the amounts of chemical inputs actually used in agricultural fields are often far above the recommended doses (Bejarano 2017). In recent years in Mexico, approximately 3,000 tons of active ingredients per year have been used to combat the fall armyworm (Spodoptera frugiperda Smith; Blanco et al. 2014). The overuse of pesticides has led to the development of pest resistance and the extermination of arthropod communities, killing not only insect pests but also many beneficial insects such as predators, parasitoids and detritivores (animals that contribute to the decomposition of dead organic material; Attwood et al. 2008; Bengsston et al. 2005; Flores-Gutiérrez et al. 2020; Theiling and Croft 1988). This can result in the loss of the ecosystem services that native predators and parasitoids may provide (Chapin et al. 2000; Desneux et al. 2007; Isaacs et al. 2009; Losey and Vaughan 2006; Zhang et al. 2007).

Mexico has a long tradition of maize agriculture. For centuries, small-scale farmers in Mexico have developed local maize landraces, with 41-65 landraces recognized today (Kato et al. 2009). Until the mid twentieth century, maize was mainly cultivated in the milpa system. This is a highly diversified system that involves high intra- and inter-species diversity and a profound local knowledge of the use of all the species of plants and animals found there to regulate pests and maintain soil health and nutrition, as well as for medical uses and food security (Martínez et al. 2020; Rodríguez-Robayo et al. 2020). Today, maize produced in the context of small farms, for example, covers not only subsistence needs, but also produces a surplus for local and regional animal and human needs (Bellón et al. 2021). However, beginning in the second half of the twentieth century, Mexico's state policies promoted the green revolution's technological schemes, including monoculture, mechanization, commercial varieties and synthetic fertilizers and pesticides (Aguilar et al. 2003). Traditional agricultural practices like the milpa are now facing challenges such as a lack of younger generations incorporating into agriculture, low commercial value of milpa products, and state and agroindustry pressure on small farmers to consume synthetic agrochemicals (Ebel et al., 2017; Orozco and Astier 2021).
Most of the beneficial aspects of traditional low-input maize cultivation are not well appreciated, and there are few studies that directly compare traditional versus conventional management. Therefore, the aim of this investigation was to evaluate the effects of conventional versus low-input agriculture on arthropod communities under two irrigation systems in Michoacán, México. Our hypothesis was that arthropod diversity would be higher in low-input rainfed agricultural plots.

\section{Methods \\ Study sites}

This study was performed during the 2011 agricultural cycle in central Michoacán, Mexico. We chose two localities with different maize cultivation practices; one depended on rainfall only $(\mathrm{R})$, and the other used irrigation (I). In each locality we chose plots under low (LI) and high-input (HI) management. The rainfed only locality was in Cherán $\left(19^{\circ} 41^{\prime} \mathrm{N}\right.$ and $\left.101^{\circ} 57^{\prime} \mathrm{W}\right)$ at $2400 \mathrm{~m}$ asl, with temperatures that range between $6-26^{\circ} \mathrm{C}$ with $1000 \mathrm{~mm}$ annual precipitation. The irrigated locality was in Álvaro Obregón (19 $\left.48^{\prime} \mathrm{N}, 101^{\circ} 02^{\prime} \mathrm{W}\right)$ at $1800 \mathrm{~m}$ asl with $918 \mathrm{~mm}$ annual precipitation and temperatures between 12 and $27^{\circ} \mathrm{C}$ (INEGI 2008).

In each locality, we located six 1 ha. maize fields-three managed with conventional high-input management $(\mathrm{HI}$; chemical fertilization, herbicide, and insecticide applications) and three with low-input management (LI; green manure and composted animal manure for fertilization and manual weed removal, Table 1 ). Thus, in total we had twelve plots (six per locality). Plots were separated by at least $500 \mathrm{~m}$ in each locality, and the farmers had followed the same management strategy for at least three consecutive years in the selected plots. After maize harvest, five composite soil samples were collected (25 cm depth) from all plots. Soil samples were sieved at $2 \mathrm{~mm}$ and air-dried until constant air-dried weight was achieved. We characterized soil texture and determined phosphorous content determined following the Olsen and Dean (1965) method, total Nitrogen content by the Kjeldahl method, and soil organic matter using the Walkley and Black method (1934) and the Cation Exchange Capacity following SEMARNAT (2002).

\section{Arthropod and maize sampling}

In each maize field, we sampled arthropod diversity three times during the agricultural cycle in July, August and September 2011. We used nine pitfall traps located in the center of each plot, arranged in three lines separated by $3 \mathrm{~m}$, as recommended by Duelli et al. (1999). Pitfall traps consisted of buried $250 \mathrm{~mL}$ plastic cups half filled with soapy water and $10 \mathrm{ml}$ of ethanol. To prevent the water from evaporating and rainfall from accumulating, the 
Table 1 Characterization of plot management including external inputs and soil characteristics

\begin{tabular}{|c|c|c|c|c|}
\hline \multirow[t]{2}{*}{ Inputs/soil characteristics } & \multicolumn{2}{|l|}{ Cherán (Rainfed) } & \multicolumn{2}{|c|}{ Alvaro Obregón (Irrigated) } \\
\hline & Low input & Conventional & Low input & Conventional \\
\hline Herbicide & & $x$ & & $x$ \\
\hline Insecticide & & $x$ & & $x$ \\
\hline Fertilizer & & $x$ & & $x$ \\
\hline Green manure and animal compost & $x$ & & $x$ & \\
\hline Machinery & Animal traction & Animal traction & Tractor & Tractor \\
\hline $\mathrm{pH}$ & $5.97 \pm 0.07$ & $6.17 \pm 0.08$ & $7.61 \pm 0.18$ & $7.52 \pm 0.09$ \\
\hline Organic matter (\%) & $3.4 \pm 1.4$ & $2.55 \pm 0.53$ & $3.06 \pm 0.52$ & $2.73 \pm 0.02$ \\
\hline$N(\%)$ & $0.1 \pm 0.02$ & $0.2 \pm 0.07$ & $0.15 \pm 0.02$ & $0.12 \pm 0.003$ \\
\hline P Olsen ppm & $5.7 \pm 1.2$ & $7 \pm 0.6$ & $20 \pm 6.53$ & $30.7 \pm 7.2$ \\
\hline CEC & $18.5 \pm 6.6$ & $22.3 \pm 5.84$ & $33.65 \pm 11.5$ & $46.97 \pm 0.68$ \\
\hline Texture & Clay & Clay & Clay Loam & Clay Loam \\
\hline
\end{tabular}

The following soil characteristics were measured at the National Soil Fertility and Vegetable Nutrition Laboratory: texture (sand, clay and silt), pH, organic matter (\% Walkley-Black), total nitrogen (\%), phosphorus (Olsen ppm), and cation exchange capacity (CEC). We sampled 12 plots in total, sample size $\mathrm{N}=3$ per treatment combination

cups were covered with plastic plates supported on metal legs $3 \mathrm{~cm}$ above the rim of the cup. Pitfall traps were left open for $96 \mathrm{~h}$ in each sampling period. The arthropods collected were sorted and identified in the laboratory using taxonomic keys and regional arthropod guides (Borror et al. 1989; White and Peterson 1998; Eaton and Kaufman 2007). We identified all taxa as morphospecies to the highest degree of detail possible, a technique known as "taxonomic sufficiency" (Ellis 1985) or "lowest practical taxonomic level" (LPT) (e.g., Hanula et al. 2009). A morphospecies can be defined as a group of biological organisms whose members differ from all other groups in some aspect of their form and structure, or species that can be distinguished from other species by their external morphology (Hale et al. 2005). We also assigned a trophic guild for each morphospecies, considering the Order or Family to which they belonged using Insect identification guides (Borror et al. 1989; White and Peterson 1998; Eaton and Kaufman 2007) and the Naturalista (https:// www.naturalista.mx) and Enciclovida (https://enciclovida.mx) web pages. When a morphospecies belonged to a Family where several trophic guilds have been reported, the guild was defined as "Other" and was not considered for the statistical analysis.

Since we were interested in linking agricultural practices with arthropod diversity and maize production, we measured cumulative herbivore damage to maize in October 2011. We quantified herbivore damage on the fourth developed leaf from the top of 20 plants per maize field using a $10 \times 10 \mathrm{~cm}$ transparent acetate with a $1 \times 1 \mathrm{~cm}$ grid, assessing the percent leaf area damaged as the number of grid squares presenting some damage. We also estimated maize production by collecting 20 ears of corn per maize field and measuring the dry weight of 100 grains following Pérez- de-la-Cerda et al. (2007).

\section{Statistical analyses}

We pooled all of the arthropod data from different sampling periods per plot. Total arthropod diversity per maize field was calculated via the effective number of species using the coverage-based integrations of rarefaction and extrapolation of Hill numbers. This method has been recommended as the diversity measure of choice to compare species diversity across multiple assemblages that differ in sample size (Ellison 2010; Chao et al. 2014; Hsieh et al. 2016). We assessed the more widely used Hill numbers, species richness (which does not consider species abundance), Shannon diversity (which counts species in proportion to their abundances, thus assessing the effective number of common species) and Simpson diversity (which discounts all but the dominant species; Chao et al. 2014; Hsieh et al. 2016). To calculate these indices for each maize plot, species abundances were pooled for the three sampled periods per plot. We used the $\mathrm{R}$ package iNEXT ( $\mathrm{R}$ Development Core Team 2008) to compute rarefaction and extrapolation sampling curves (Hsieh et al. 2016).

Using the calculated Hill numbers and different abundances, we analyzed the effect of management type and site on arthropod community attributes using nested ANOVAs. The response variables were species richness, Shannon diversity, Simpson diversity, total abundance, morphospecies abundance, Order abundance and guild abundance. The explanatory variables were management 
(low-input or high-input) nested within site (irrigated or rainfed). Herbivory and maize production per plot were also analyzed using nested ANOVAs. Abundances and maize production were log-transformed to comply with ANOVA assumptions.

Similarities in arthropod composition per maize field were analyzed using non-metric dimensional scale analyses (NMDS), with morphospecies abundance per plot. We calculated a Bray-Curtis dissimilarity matrix between plots. This ordination method is recommended since it can detect gradients without assuming linear relationships between variables (Quinn and Keough 2002) and produces an ordination based on a distance or dissimilarity matrix. We used the metaMDS and adonis functions from the vegan package for $\mathrm{R}$ ( $\mathrm{R}$ Development Core Team 2008). To obtain a probabilistic statement of statistical differences in the community composition across the sampling sites, we used a permutational non-parametric multivariate analysis of variance (PERMANOVA, Anderson 2001; McArdle and Anderson 2004) using the Bray-Curtis distance metric. This test allows the evaluation of the null hypothesis that groups (in this case, management types) do not differ in their species compositions. First, $F$ statistics are recalculated after a random shuffling of the labels on the rows that identify them as belonging to a particular group. This is repeated for all possible re-orderings of the rows relative to the labels, to create a distribution of pseudo $F$ values, which is then used to compare the $F$ value calculated with the original ordering of the data, yielding a $P$ value to test the null hypothesis (Anderson 2001).

All statistical analyses were performed in the $\mathrm{R}$ environment (R Development Core Team 2008).

\section{Results}

\section{Arthropod abundance and diversity}

We collected a total of 14,315 individual arthropods belonging to 5 Classes (Arachnida, Malacostraca, Insecta, Diplopoda and Myriapoda), 12 Orders, 42 Families and 204 morphospecies (Additional file 1: Table S1). The Orders with the most morphospecies were Coleoptera (77), Diptera (31), Araneae (28), Hemiptera (36) and Hymenoptera (16). The arthropod abundance was highest for Coleoptera (3870 individuals), Diptera (3775 individuals), Hymenoptera (1841), and Collembola (1780 individuals) which together accounted for $79 \%$ of all of the individuals collected during the study. Four very abundant species-one Collembola, one Coleopteran, one Dipteran and one Hymenopteran-accounted for $39 \%$ of all individuals $(1780,1463,1424$ and 904 individuals respectively). We also trapped one vertebrate in one of the sampling periods, which was identified as the rat Oryzomys couesi (Alston, 1877) (Fig. 1).
The most abundant insects considered to be pests were Nicentrus testaceipes (Coleoptera), Macrodactylus sp. (Coleoptera), Diabrotica sp. (Coleoptera), Dalbulus maidis (Hemiptera), Rhopalosiphum maidis (Hemiptera), Gryllus rubens (Orthoptera) and Spodoptera frugiperda (Lepidoptera). The most abundant predators were Forficula sp. (Dermaptera), Orius sp. (Hemiptera), Calosoma sp. (Coleoptera) and four species of Formicidae.

Total abundance was highly variable among plots. On average there were $999.5 \pm 373.3$ arthropods/plot in highinput plots and $1386.3 \pm 373$ arthropods in low-input plots; there was no significant difference in abundance between management types (Low-input vs. High- input: $\left.\mathrm{F}_{(1,8)}=2.76, \mathrm{p}=0.13\right)$ or sites within each management type (Rainfed vs. Irrigated: $\mathrm{F}_{(1,2)}=9.67, \mathrm{p}=0.09$, Fig. 2), although low-input irrigated plots tended to have higher abundances. Similarly, the diversity estimators did not show differences between management types or sites either (Richness: management: $\mathrm{F}_{(1,8)}=2.25, \mathrm{p}=0.17$, site $F_{(1,2)}=0.2, p=0.7$, Shannon est: management $F_{(1,8)}=0.3$, $p=0.6$ and site: $F_{(1,2)}=0.09, p=0.78$, Simpson est: management $\mathrm{F}_{(1,8)}=0.001, \mathrm{p}=0.99$ and management/site: $\mathrm{F}_{(1,2)}=0.0001, \mathrm{p}=0.99$, respectively). The abundance of different arthropod Orders per plot was similar between sites and management types, except for Hymenoptera, which was more abundant in the low input plots (Table 2).

\section{Arthropod community composition and trophic guilds}

Arthropod community composition was very similar among plots in one locality, the rainfed site ( $\mathrm{R}$ locality, Cherán, Fig. 3). At the site with irrigation (I) (Alvaro Obregón), however, low-input plots were strongly significantly different from high-input plots (PERMANOVA: $\left.\mathrm{r}^{2}=0.9532 \mathrm{p}=0.001\right)$. This analysis shows that there are differences between the centroids.

The analysis of arthropod guilds showed that morphospecies that could be categorized as predators or herbivores from the literature were more abundant in low-input plots $\left(\mathrm{F}_{(1,8)}=7.74, \mathrm{p}=0.02\right.$ and $\mathrm{F}_{(1,8)}=6.39$, $\mathrm{p}=0.03$, respectively, Fig. 4). For herbivores, this difference was more pronounced in irrigation plots, while detritivores were particularly variable between plots, with no apparent differences between management types $\left(\mathrm{F}_{(1,8)}=4.33, \mathrm{p}=0.07\right)$. There were no differences in guild abundances between sites $(\mathrm{p}>0.05)$.

\section{Herbivory and maize production}

Maize leaf damage was $10.24 \pm 6.4 \%$ on average in all management types; there were no significant differences between management types or sites (management: $\mathrm{HI}=9.85 \pm 4.6 \%$ damage and $\mathrm{LI}=8.27 \pm 3.06 \%$ damage, $\mathrm{F}(1,8)=2.67, \mathrm{p}=0.11$; and sites: $\mathrm{R}=9.8 \pm 1.95 \%$ 


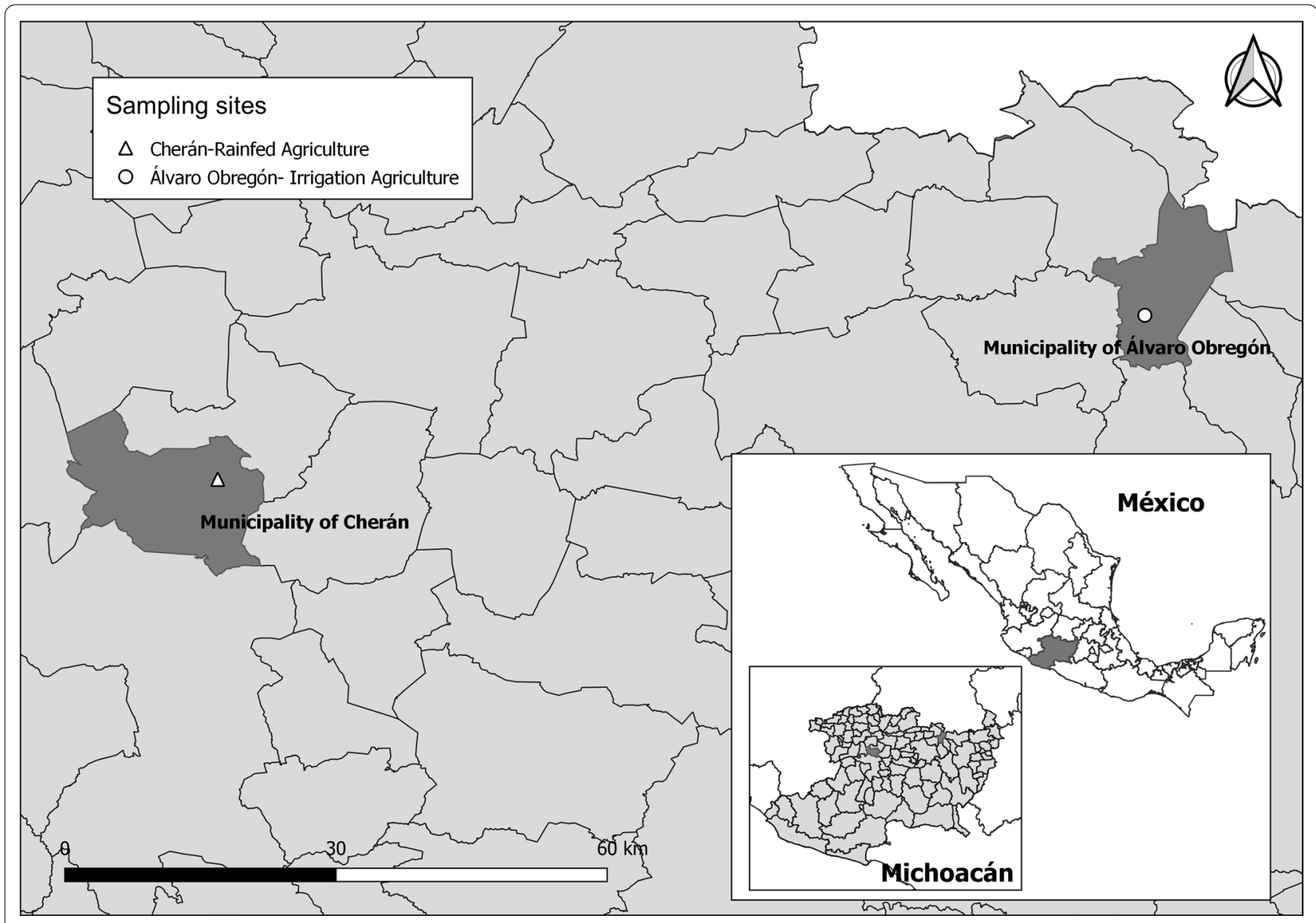

Fig. 1 Map showing study sites in Cherán and Alvaro Obregón, Michoacán, Mexico

damage and $I=10.24 \pm 6.43 \%$ damage, $F(1,2)=1.13$, $\mathrm{p}=0.29$ ). Maize production estimated as the dry weight of 100 grains per plot did not differ between management types or sites, with an overall average of $26 \pm 8.6 \mathrm{~g}$ /100grains (management: $\mathrm{HI}=29.2 \pm 5.5 \mathrm{~g} / 100$ grains and $\mathrm{LI}=22.7 \pm 10.7 \mathrm{~g} / 100$ grains, $\mathrm{F}(1,8)=2.42, \mathrm{p}=0.15$; and sites: $\mathrm{R}=29.3 \pm 7.2 \mathrm{~g} / 100 \mathrm{grains}$ and $\mathrm{I}=24.7 \pm 8.8 \mathrm{~g}$ /100grains, $\mathrm{F}(1,2)=1.13, \mathrm{p}=0.29$ ).

\section{Discussion}

This investigation found that agricultural maize management practices have some significant effects on arthropod communities. In particular, it was evident that high-input management involving the frequent use of chemical inputs (insecticides, herbicides and fertilizer) had a negative effect upon Hymenoptera (mainly ants) and therefore a negative effect on predators.

Most maize agriculture in Mexico is now strongly dependent on external inputs (Hernández-Antonio and Hansen 2011). However, these changes in management practices do not necessarily translate into higher yields and economic profits. The application of external inputs without technical guidance can cause pest resistance, soil depletion, increase of herbivore populations due to lack of land rest, and other detrimental effects (Arnés et al. 2013; León-García et al. 2012). In our study case, herbivores and predators showed higher abundances in low-input plots. On average, predators were twice and three times as abundant in low-input plots compared with high-input ones in the rainfed and irrigated plots, respectively. This pattern suggests that chemical insecticides are not only affecting pest species, but also their predators. Other investigations have also found this pattern; Letourneau and Goldstein (2001) found greater predator abundances on organic farms compared to farms under conventional management, and in a recent global synthesis, Lichtenberg et al. (2017) concluded that organic farming provides better conditions for predators. In another recent study, Rosas-Ramos et al. (2020) found that organic management of cherry orchards benefited parasitoids and pollinators, though not predators. When comparing organic versus high-input farming, it has been difficult to determine the effect of stopping insecticide and/or herbicide use for arthropod communities. Most 


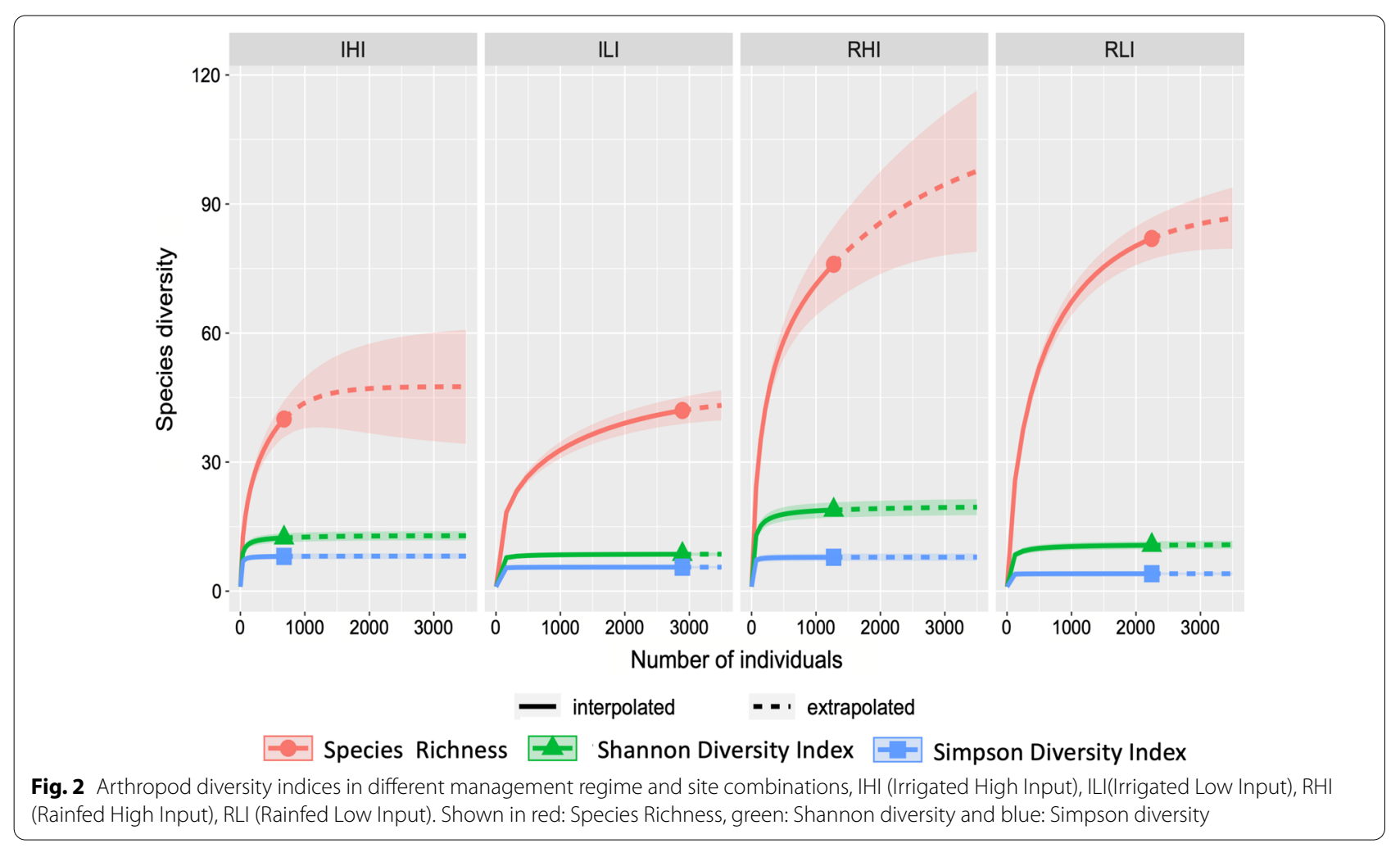

Table 2 Nested ANOVA of the effect of site and management on different arthropod orders, showing the degrees of freedom (d.f.), $F$ and $P$ values

\begin{tabular}{|c|c|c|c|c|c|c|}
\hline \multirow[t]{2}{*}{ Order } & \multicolumn{3}{|c|}{ Site } & \multicolumn{3}{|c|}{ Management } \\
\hline & d.f & $F$ & $P$ & d.f & $F$ & $P$ \\
\hline Araneae & 1,2 & 0.42 & 0.58 & 1,8 & 2.94 & 0.12 \\
\hline Coleoptera & 1,2 & 0.42 & 0.58 & 1,8 & 2.94 & 0.12 \\
\hline Diptera & 1,2 & 0.007 & 0.94 & 1,8 & 0.15 & 0.71 \\
\hline Hemiptera & 1,2 & 0.54 & 0.53 & 1,8 & 3.72 & 0.09 \\
\hline Hymenoptera & 1,2 & 0.42 & 0.58 & 1,8 & 29.5 & 0.0006 \\
\hline Orthoptera & 1,2 & 1.57 & 0.33 & 1,8 & 3.61 & 0.09 \\
\hline Collembola & 1,2 & 0.14 & 0.74 & 1,8 & 0.83 & 0.39 \\
\hline Spirobolida & 1,2 & 0.02 & 0.91 & 1,8 & 1.1 & 0.32 \\
\hline
\end{tabular}

Significant effects are highlighted in italics

Orders with $<50$ individuals were not analyzed

studies have found that increasing plant diversity within agricultural plots by intercropping or using cover crops is beneficial for predators (Philpott et al. 2006; Geldenhuys et al. 2021; Mhlanga et al. 2020; Del Pedro et al. 2020; Saenz Romo et al. 2019; Rivers et al. 2016; Otieno et al. 2019). Also, increasing plant diversity along field margins has proven to benefit predator abundances in some sites (Mkenda et al. 2019, Rusch et al. 2016). One aspect that warrants further investigation that is highlighted in the study by Tschumi et al. (2018) and Flores-Gutiérrez et al. (2020) and warrants further investigation is that the effect of seminatural habitats surrounding crops on the services or disservices of arthropods depends on the ecosystem type and region (e.g. dry versus wet forests).

In our study, ants were the predators that benefited the most from low-input agriculture; at the irrigated site they increased 100-fold, while in the rain-fed they increased twofold. This result is very significant, since ants have been shown to be important pest controllers for several (Thurman et al 2019; Philpott and Armbrecht 2006) 


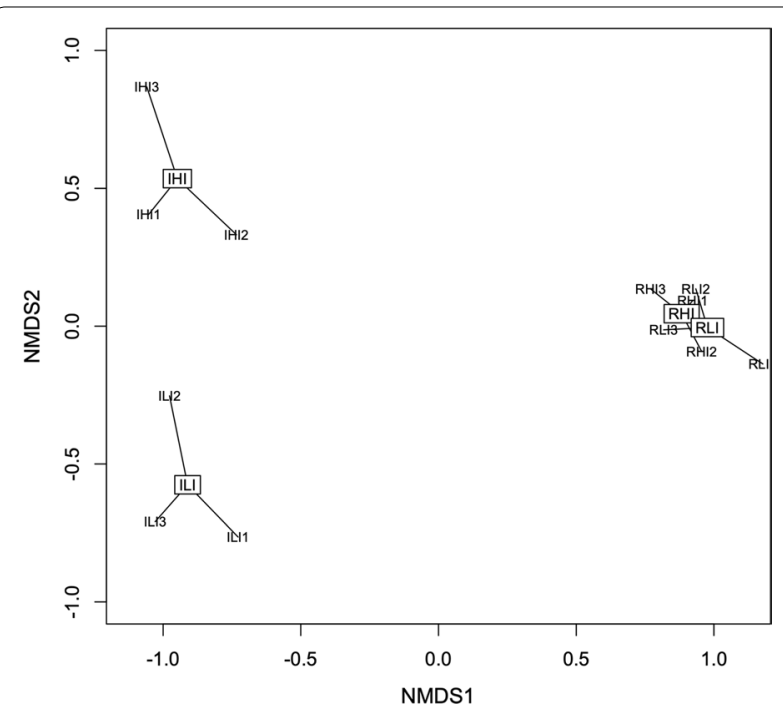

Fig. 3 Non-multidimensional scaling analysis showing different plots from different sites and management practices. A clear cluster was formed with the plots from the rainfed-Cherán site (Low and High input, RHI and RLI) while irrigated-Alvaro Obregón showed two different communities depending on management regime (Low and High Input, LHI and ILI)

including maize agroecosystems (Perfecto 1991; Perfecto and Castiñeiras 1998). Ants are known to be important egg-predators (Wills et al. 2019) and they can also prey on larvae, pupae and adult insects (Perfecto 1990, 1991). Other studies have also found that management affect ant community composition and predation effects, in particular maize fields sown surrounded by forested areas have shown to have higher ant predation rates than clear maize fields (Risch and Carroll 1982). In our study, in addition to avoiding the use of insecticides, low-input fields also have more diverse vegetation, which may have provided more prey for ants.

Insecticides were developed during the green revolution to control pest damage to crops (FAO 2003). Since then, insecticides are used heavily throughout the world with benefits to production but without consideration for insect diversity or other services provided by insects (Akanksha et al. 2020, Dirzo et al. 2014, Hallman et al. 2017; Klink et al. 2020). Insecticides currently have highly variable effects on crop production and pest reduction (Rosenheim 2021; Emery et al. 2021). In our study sites, high-input farmers cultivating in irrigated or rainfed regimes spend a considerable amount of money buying insecticides, which apparently does not translate into a considerable reduction of herbivores or herbivory levels on plants (Arnés et al. 2013), since herbivore damage to plants was similar between management regimes (high-input vs. low-input), so the expense of insecticide did not translate into protection of plants from herbivores. Furthermore, although we do not have an estimate of total maize production per plot, we found that maize grain weight was similar between treatments, suggesting that the differences on external inputs did not result in a strong increase in maize production. Similar results were found in papaya cultivation in western Mexico (FloresGutiérrez et al. 2020) and in corn cultivated in northern California, USA (Clark et al. 1998). Despite evidence to

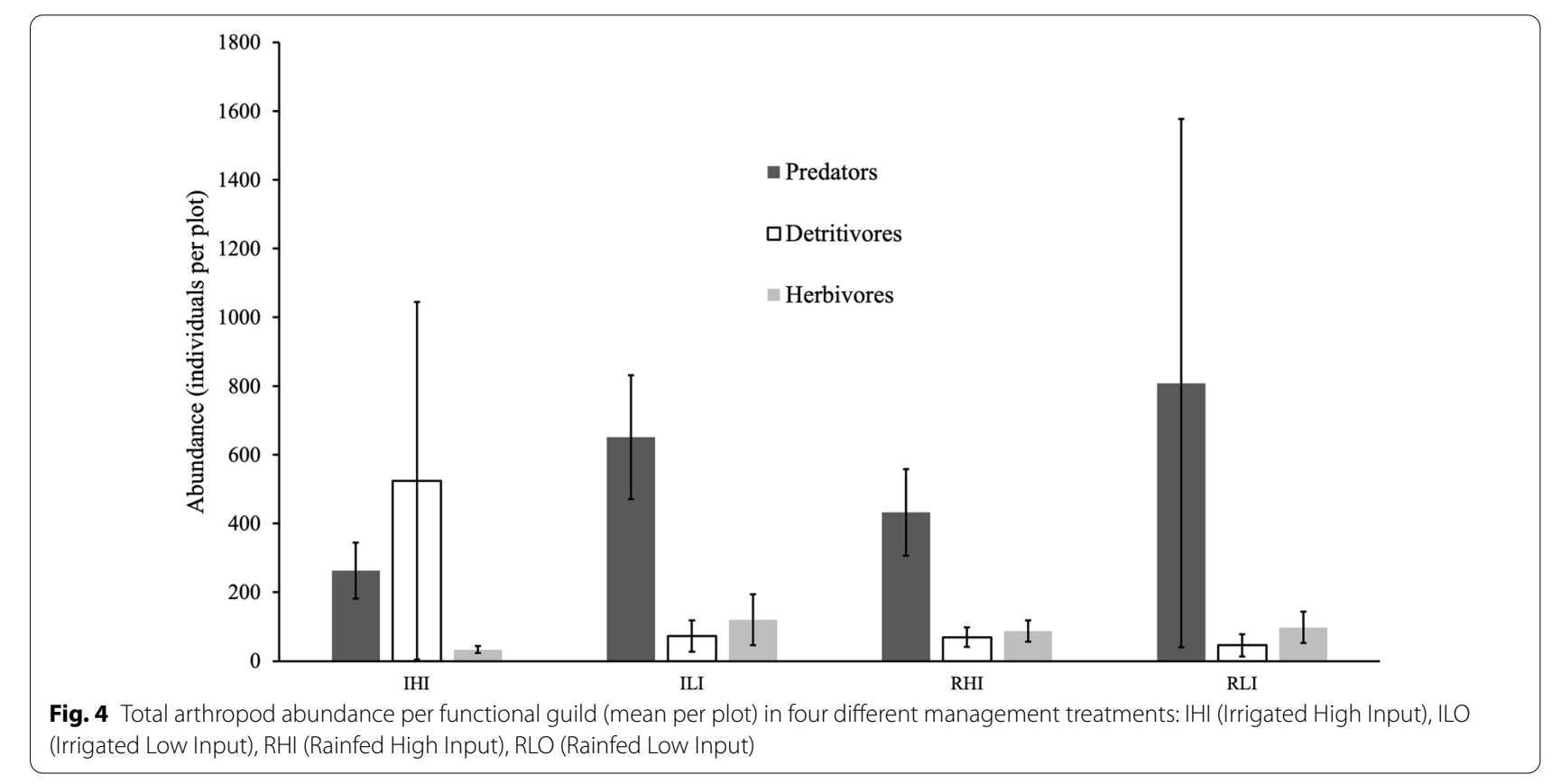


the contrary, conventional farmers often feel that it is too risky to stop using insecticide, so the transition towards more sustainable agriculture has to be gradual, and results from this type of investigation should be shared with farmers.

Another aspect to take into consideration is that herbivore impacts are normally considered to be directly and linearly related with plant productivity, but this not always the case (Perez-Alvarez et al. 2018; Poveda et al. 2003, 2010). We need more studies looking into real herbivore population thresholds that affect crop production to allow sustainable pest management based on local data. In our study system, maize in low-input management plots appears to cope with the levels of herbivory without a decrease in productivitt, suggesting some kind of compensation.

\section{Conclusions}

Agricultural management regime had a significant effect upon arthropod communities in both rainfed and irrigated maize farms. Given that arthropod species are experiencing significant declines worldwide, low-input management could contribute to conservation. The plots under conventional maize management at both irrigated and rain-fed sites used several costly external inputs, but did not have significantly reduced herbivores or maize damage, suggesting that alternative solutions would be able to control pest damage.

\section{Supplementary Information}

The online version contains supplementary material available at https://doi. org/10.1186/s43170-021-00060-9.

Additional file 1. Arthropods found during the study period. Showing their taxonomic status, guild, common name and scientific name for the most abundant species.

\section{Acknowledgements}

Thanks to the maize producers in Aranza Cherán and Alvaro Obregón for allowing us to monitor their maize plots, especially to Mauricio Ponce de León and Javier Gabriel Pedro. Thanks to Lizet Solis and Nallely Luviano for their valuable help during the fieldwork and insect identification. We thank Ana Clara Plá for drawing the map of the study area. The manuscript was revised by the professional English translator Lynna Kiere.

\section{Authors' contributions}

EDV and MA designed the project and sampling design. ER performed the field work, identify the arthropods and made preliminary analysis. EDV performed statistical analysis and wrote the manuscript. MA and ER made substantial contributions in manuscript.

\section{Funding}

This work was supported by Conacyt -SEMARNAT (Project 2008-C01-107978) and DGAPA-UNAM (Project BG200720).

\section{Availability of data and materials}

The datasets during and/or analyzed during the current study available from the corresponding author on reasonable request.

\section{Declarations}

Ethics approval and consent to participate

Arthropod sampling was conducted according to standard techniques to minimize the risk of capturing mammals or reptiles.

\section{Consent for publication}

Not applicable.

\section{Competing interests}

The authors declare that they have no competing interests.

\section{Author details}

${ }^{1}$ Instituto de Investigaciones en Ecosistemas y Sustentabilidad, Universidad Nacional Autónoma de México, Antigua Carretera a Pátzcuaro No.8701. Col. Ex Hacienda de San José de la Huerta, Morelia, Michoacán C.P. 58190, Mexico. ${ }^{2}$ Centro de Investigaciones en Geografía Ambiental, Universidad Nacional Autónoma de México, Antigua Carretera a Pátzcuaro No.8701. Col. Ex Hacienda de San José de la Huerta, Morelia, Michoacán C.P. 58190, Mexico.

Received: 2 July 2021 Accepted: 27 September 2021

Published online: 15 October 2021

\section{References}

Akanksha S, Shuklaa A, Attria K, Kumare M, Kumarf P, Sutteeg A, Singhb G, Barnwala RO, Singlaa N. Global trends in pesticides: A looming threat and viable alternatives. Ecotoxicol Environ Saf. 2020;201: 110812. https://doi. org/10.1016/j.ecoenv.2020.110812.

Aguilar J, Illsley C, Marielle C. Los sistemas agrícolas de maíz y sus procesos técnicos. In: Esteva G, Marielle C, editors. Sin maíz no hay país. México: Conaculta Ciudad de México; 2003. p. 83-122.

Arnés E, Antonio AJ, del Val E, Astier M. Sustainability and climate variability in low-input peasant maize systems in the central Mexican highlands. Agr Ecosyst Environ. 2013;181:195-205. https://doi.org/10.1016/j.agee.2013. 09.022.

Arnett RA Jr. American insects. A handbook of the insects of North America. 2nd ed. Boca Raton, FL: CRC Press; 2000. p. 1003.

Attwood SJ, Maron M, House APN, Zammit C. Do arthropod assemblages display globally consistent responses to intensified agricultural land use and management? Glob Ecol Biogeogr. 2008;17:585-99. https://doi.org/ 10.1111/j.1466-8238.2008.00399.x.

Bejarano F. Los Plaguicidas Altamente Peligrosos en México. Red de Acción sobre Plaguicidas y Alternativas en México, Centro de Investigación en Alimentación y Desarrollo, Instituto Nacional de Investigaciones Forestales, Agrícolas y Pecuarias, International POPs Elimination Network - Programa de las Naciones Unidas para el Desarrollo, Universidad Autónoma de Nayarit, Red Temática de Toxicología de Plaguicidas, Red de Acción en Plaguicidas y sus Alternativas para América Latina, Universidad Autónoma del Estado de México, Unión de Científicos Comprometidos con la Sociedad, Texcoco, Estado de México. 2017.

Bengtsson J, Ahnström J, Weibull AC. The effects of organic agriculture on biodiversity and abundance: a meta-analysis. J Appl Ecol. 2005;42:261-9. https://doi.org/10.1111/j.1365-2664.2005.01005.X.

Blanco CA, Pellegaud G, Nava-Camberos U, Lugo-Barrera D, Vega-Aquino P, Coello J, Teraán-Vargas A, Vargas-Camplis J. Maize Pests in Mexico and Challenges for the Adoption of Integrated Pest Management Programs. J Integrat Pest Management. 2014;5:1-9. https://doi.org/10.1603/IPM14 006.

Borror DJ, Triplehorn CA, Johnson NF. An introduction to the study of insects. 6th ed. Fort Worth: Saunders College Publishing; 1989. p. 875.

Brian H, McArdle Marti J, Anderson. Variance heterogeneity transformations and models of species abundance: a cautionary tale. Canadian Journal of Fisheries and Aquatic Sciences. 2004;61 (7):1294-1302. https://doi.org/10. 1139/f04-051.

Caspar A., Hallmann Martin, Sorg Eelke, Jongejans Henk, Siepel Nick, Hofland Heinz, Schwan Werner, Stenmans Andreas, Müller Hubert, Sumser Thomas, Hörren Dave, Goulson Hans, de Kroon Eric Gordon, Lamb More than 75 percent decline over 27 years in total flying insect biomass in 
protected areas. PLOS ONE. 2017;12(10):e0185809. https://doi.org/10. 1371/journal.pone.0185809.

Chao A, Gotelli NJ, Hsieh TC, Sande EL, Ma KH, Colwell RK, Ellison AM. Rarefaction and extrapolation with Hill numbers: a framework for sampling and estimation in species diversity studies. Ecol Monogr. 2014;84:45-67. https://doi.org/10.1890/13-0133.1.

Chapin FS III, Zavaleta ES, Eviner VT, Naylor RL, Vitousek PM, Reynolds HL, Hooper DU, Lavorel S, Sala OE, Hobbie SE, Mack MC, Díaz S. Consequences of changing biodiversity. Nature. 2000;405:234-42.

Clark MS, Ferris H, Klonskyc K, Laninid WT, van Bruggene HC, Zalom FG. Agronomic, economic, and environmental comparison of pest management in conventional and alternative tomato and corn systems in northern California. Agr Ecosyst Environ. 1998;68:51-71. https://doi.org/10.1016/ S0167-8809(97)00130-8.

de Pedro L, Perera-Fernandez LG, Lopez-Gallego E, Perez-Marcos M, Sanchez JA. The Effect of Cover Crops on the Biodiversity and Abundance of Ground-Dwelling Arthropods in a Mediterranean Pear Orchard. Agronomy. 2020;10:580. https://doi.org/10.3390/agronomy10040580.

Desneux N, Decourtye A, Delpuech JM. The sublethal effects of pesticides on beneficial arthropods. Annu Rev Entomol. 2007;52:81-106.

Dirzo R, Young HS, Galetti M, Ceballos G, Isaac NJB, Collen B. Defaunation in the Anthropocene. Science. 2014;345:401-6. https://doi.org/10.1126/ science. 1251817

D.K, Letourneau B, Goldstein. Pest damage and arthropod community structure in organic vs. conventional tomato production in California. Journal of Applied Ecology. 2001;38(3) 557-570 https://doi.org/10.1046/j.13652664.2001.00611.x.

Duelli P, Obrist MK, Schmatz DR. Biodiversity evaluation in agricultural landscapes: above-ground insects. Agric Ecosyst Environ. 1999;74:33-64 https://doi.org/10.1016/50167-8809(99)00029-8.

Eaton, E.R., Kaufman, K. (2007). Kaufman Field Guide to Insects of North America. Houghton Mifflin. 392 pp

Ebel R, Pozas JGC, Soria FM, Cruz JG. Manejo orgánico de la milpa: rendimiento de maíz, frijol y calabaza en monocultivo y policultivo. Terra Latinoamericana. 2017;35:149-60. https://doi.org/10.28940/terra.v35i2.166.

Ellis, D. Taxonomic sufficiency in pollution assessment. Marine Pollution Bulletin. 1985;16(12):459.

Ellison AM. Partitioning diversity. Ecology. 2010;91:1962-3. https://doi.org/10. 1890/09-1692.1

Emery SE, Jonsson M, Silva H, Ribeiro A, Mills NJ. High agricultural intensity at the landscape scale benefits pests, but low intensity practices at the local scale can mitigate these effects. Agr Ecosyst Environ. 2021;306: 107199. https://doi.org/10.1016/j.agee.2020.107199.

Encliclovida. https://enciclovida.mx.

FAO. Agricultura orgánica, ambiente y seguridad alimentaria. Serie sobre medio ambiente y recursos naturales. № 4 . Ed. Scialabba, N., Hattam, C. Roma. 2003. 259p.

Flores-Gutiérrez A, Mora F, Avila-Cabadilla LL, Boege K, del-Val, E. . Assessing the cascading effects of management and landscape on the arthropod guilds occurring in papaya plantations. Agr Ecosyst Environ. 2020;293: 106836. https://doi.org/10.1016/j.agee.2020.106836.

Geldenhuys M, Gaigher R, Pryke JS, Samways MJ. Diverse herbaceous cover crops promote vineyard arthropod diversity across different management regimes. Agr Ecosyst Environ. 2021;30: 107222. https://doi.org/10. 1016/j.agee.2020.107222.

Hale WG, Saunders VA, Margham JP, Hernández-Antonio A, Hansen AM. Uso de plaguicidas en dos zonas agrícolas de México y evaluación de la contaminación y sedimentos. Revista Internacional De Contaminación Ambiental. 2011;27:115-27.

Hanula, J. L., Wade, D. D., O'Brien, J. \& Loeb, S. C. (2009). Ground-dwelling arthropod association with coarse woody debris following long-term dormant season prescribed burning in the longleaf pine flatwoods of north Florida. Florida Entomologist, 92(2), 229-242.

Hernández-Antonio, A., and Hansen, A.M. (2011) Uso de plaguicidas en dos zonas agrícolas de México y evaluación de la contaminación y sedimentos. Revista Internacional de Contaminación Ambiental, 27, 115-127.

Hsieh TC, Anne CK, Ma H. iNEXT: an R package for rarefaction and extrapolation of species diversity (Hill numbers). Methods Ecol Evol. 2016;7:1451-6. https://doi.org/10.1111/2041-210X.12613.

Isaacs R, Tuell J, Fiedler A, Gardiner M, Landis D. Maximizing arthropod mediated ecosystem services in agricultural landscapes: the role of native plants. Front Ecol Environ. 2009;7:196-203. https://doi.org/10.1890/ 080035.

Katja, Poveda María Isabel Gómez, Jiménez André, Kessler. The enemy as ally: herbivore-induced increase in crop yield. Ecological Applications. 2010;20(7):1787-1793. https://doi.org/10.1890/09-1726.1.

Katja, Poveda María F., Díaz Augusto, Ramirez. Can overcompensation increase crop production?. Ecology. 2018;99(2):270-280. https://doi.org/10.1002/ ecy.2088.

Lehmann $\mathrm{P}$, Ammunét T, Barton M, Battisti A, Eigenbrode SD, Uhd Jepsen J, Kalinkat G, Neuvonen S, Niemelä P, Terblanche JS, Økland B, Björkman C. Complex responses of global insect pests to climate warming. Front Ecol Environ. 2020;18:141-50. https://doi.org/10.1002/fee.2160.

León-García I, Rodríguez-Leyva E, Ortega-Arenas LD, Solís-Aguilar JF. Susceptibilidad de Spodoptera frugiperda (J.E. Smith) (Lepidoptera: Noctuidae) a insecticidas asociada a césped en Quintana Roo México. Agrociencia. 2012:46:279-87.

Lichtenberg EM, Kennedy CM, Kremen C, et al. A global synthesis of the effects of diversified farming systems on arthropod diversity within fields and across agricultural landscapes. Glob Change Biol. 2017;23:4946-57. https://doi.org/10.1111/gcb.13714.

Losey JE, Vaughan M. The economic value of ecological services provided by insects. Bioscience. 2006;56:311-23.

Marti J., Anderson. A new method for non-parametric multivariate analysis of variance. Austral Ecology. 2001;26(1):32-46. https://doi.org/10.1111/j. 1442-9993.2001.01070.pp.x.

Martínez DYP, Sánchez JE, Rodríguez MNM, Astier MC. (2020) Sustentabilidad de agroecosistemas de milpa en La Trinidad Ixtlán Revista de la Facultad de Agronomía. La Plata. 119: 1-16. https://doi.org/10.24215/16699513e0 48.

Mhlanga B, Muoni T, Mashavakure N, Mudadirwa D, Mulenga R, Sitali M, Thierfelder C. Friends or foes? Population dynamics of beneficial and detrimental aerial arthropods under Conservation Agriculture. Biol Control. 2020;148: 104312. https://doi.org/10.1016/j.biocontrol.2020.104312.

Naturalista. https://www.naturalista.mx/home.

Numa C, Tonelli M, Lobo JM, Verdú JR, Lumaret JP, Sánchez-Piñero F, Ruiz JL, Dellacasa M, Ziani S, Arriaga A, Cabrero F, Labidi I, Barrios V, ŞenyüzY, Anlaş $\mathrm{S}$. The conservation status and distribution of Mediterranean dung beetles. Malaga: IUCN; 2020

Olsen SR, Dean LA. Phosphorus. In: Methods of soil analysis Part 2 Agronomy. USA: Black CA; 1965. p. 1035-49.

Orozco-Ramírez Q, Astier M. Ser campesino y sembrar milpa hoy, como estrategia de adaptación y resistencia. In: Borrego A, Ramírez I, Astier M. Integración global: El nuevo entorno de los territorios locales. Editorial CIGA, UNAM, Morelia. 2021.

Otieno NE, Pryke JS, Butler M, Jacobs SM. Top-down suppression of arthropod herbivory in intercropped maize and organic farms evidenced from $\delta 13 C$ and $815 \mathrm{~N}$ stable isotope analyses. Agron Sustain Dev. 2019;39:1-10. https://doi.org/10.1007/s13593-019-0585-z.

Perfecto I. Indirect and direct effects in a tropical agroecosystem: the maizepest-ant system in Nicaragua. Ecology. 1990;71:2125-34.

Perfecto I. Ants (Hymenoptera: Formicidae) as Natural Contro I Agents of Pests in Irrigated Maize in Nicaragua. J Econ Entomol. 1991;84:65-70. https:// doi.org/10.1093/jee/84.1.65.

Perfecto I, Castiñeiras A. Deployment of the predaceous ants and their conservation in agroecosystems. In: Barbosa P, editor. Conservation Biological Control. San Diego: Academic Press; 1998. p. 269-89.

Pérez de la Cerda, F. de J., Córdova, T., Santacruz, A., Castillo, F., Cárdenas, E. y A. Delgado Alvarado. Relación entre vigor inicial, rendimiento y sus componentes en poblaciones de maíz chalqueño. Agricultura Técnica en México. 2007:33(1):5-16

Philipp, Lehmann Tea, Ammunét Madeleine, Barton Andrea, Battisti Sanford D, Eigenbrode Jane Uhd, Jepsen Gregor, Kalinkat Seppo, Neuvonen Pekka, Niemelä John S, Terblanche Bjørn, Økland Christer, Björkman. Complex responses of global insect pests to climate warming. Frontiers in Ecology and the Environment. 2020;18(3):141-150. https://doi.org/10.1002/fee. 2160.

Philpott SM, Armbrecht I. Biodiversity in tropical agroforests and the ecological role of ants and ant diversity in predatory function. Ecol Entomol. 2006;31:369-77. https://doi.org/10.1111/j.1365-2311.2006.00793.x.

Philpott SM, Perfecto I, Vandermeer J. Effects of management intensity and season on arboreal ant diversity and abundance in coffee 
agroecosystems. In: Hawksworth DL, Bull AT, editors. Arthropod Diversity and Conservation Topics in Biodiversity and Conservation, vol. 1. Dordrecht: Springer; 2006.

Potts SG, Biesmeijer JC, Kremen C, Neumann P, Schweiger O, Kunin WE. Global pollinator declines: trends, impacts and drivers. Trends Ecol Evol. 2010;25:345-53. https://doi.org/10.1016/j.tree.2010.01.007.

Prisila A., Mkenda Patrick A., Ndakidemi Philip C., Stevenson Sarah E. J., Arnold Steven R., Belmain Maneno, Chidege Geoff M., Gurr. Field Margin Vegetation in Tropical African Bean Systems Harbours Diverse Natural Enemies for Biological Pest Control in Adjacent Crops. Sustainability. 2019;11(22):6399. https://doi.org/10.3390/su11226399.

Quinn GP, Keough MJ. Experimental design and data analysis for biologists. Cambridge: Cambridge University Press; 2002. p. 537.

R Development Core Team. R: A Language and Environment for Statistical Computing. Vienna, Austria: R Foundation for Statistical Computing. 2008. Retrieved from https://www.R-proje ct.org.

Ricardo, Perez-Alvarez Brian A., Nault Katja, Poveda . Contrasting effects of landscape composition on crop yield mediated by specialist herbivores. Ecological Applications. 2018;28(3):842-853. https://doi.org/10.1002/eap. 1695.

Risch SJ, Carroll CR. Th e ecological role of ants in two Mexican agroecosystems. Oecologia. 1982;55:114-9.

Rivers A, Barbercheck M, Govaerts B, Verhulst N. Conservation agriculture affects arthropod community composition in a rainfed maize-wheat system in central Mexico. Appl Soil Ecol. 2016;100:81-90. https://doi.org/ 10.1016/j.apsoil.2015.12.004.

Rosas-Ramos N, Banos-Picon L, Tormos J, Asis JD. Natural enemies and pollinators in traditional cherry orchards: Functionally important taxa respond differently to farming system. Agr Ecosyst Environ. 2020;295: 106920. https://doi.org/10.1016/j.agee.2020.106920.

Rodríguez-Robayo K, Méndez-López ME, Molina-Villegas A, Juárez L. What do we talk about when we talk about milpa? A conceptual approach to the significance, topics of research and impact of the mayan milpa system. J Rural Stud. 2020;77:47-54. https://doi.org/10.1016/j.jrurstud.2020.04.029.

Roel, van Klink Diana E, Bowler Konstantin B, Gongalsky Ann B, Swengel Alessandro, Gentile Jonathan M Chase. Meta-analysis reveals declines in terrestrial but increases in freshwater insect abundances. Science. 2020;368(6489):417-420. https://doi.org/10.1126/science.aax9931.

Rosenhemin JA. Control Failures Following Insecticide Applications in Commercial Agriculture: How Often Do They Occur? A Case Study of Lygus hesperus (Hemiptera: Miridae) Control in Cotton. 2021.

Rusch A, Chaplin-Kramer R, Gardiner MM, Hawro V, Holland J, Landis D, Thies C, Tscharntke T, Weisser WW, Winqvist C. Agricultural landscape simplification reduces natural pest control: a quantitative synthesis. Agr Ecosyst Environ. 2016;221:198-204. https://doi.org/10.1016/j.agee.2016. 01.039 .

Saenz-Romo MG, Veas-Bernal A, Martinez-Garcia H, Campos-Herrera R, IbanezPascual S, Martinez-Villar E, Perez-Moreno I, Marco-Mancebon VS. Ground cover management in a Mediterranean vineyard: Impact on insect abundance and diversity. Agric Ecosyst Environ. 2019;283:106571. https:// doi.org/10.1016/j.agee.2019.106571.

SEMARNAT (Secretaría de Medio Ambiente y Recursos Naturales). Norma Oficial Mexicana NOM-021SEMARNAT-2000, que establece las especificaciones de fertilidad, salinidad y clasificación de suelos, estudio, muestreo y análisis. SEMARNT. México, D. F. 2002.

Theiling KM, Croft BA. Pesticide side-effects on arthropod natural enemies: a database summary. Agr Ecosyst Environ. 1988;21:191-218. https://doi. org/10.1016/0167-8809(88)90088-6.

Thurman JH, Northfield TD, Snyder WE. Weaver ants provide ecosystem services to tropical tree crops. Front Ecol Evol. 2019. https://doi.org/10.3389/ fevo.2019.00120.

Tschumi M, Ekroos J, Hjort C, Smith HG, Birkhofer K. Predation-mediated ecosystem services and disservices in agricultural landscapes. Ecol Appl. 2018;28:2109-18. https://doi.org/10.1002/eap.1799.

van Klink R, Bowler DE, Gongalsky KB, Swenge AB, Gentile A, Chase JM. Metaanalysis reveals declines in terrestrial but increases in freshwater insect abundances. Science. 2020;368:417-20. https://doi.org/10.1126/science. aax9931.

Walkley A, Black IA. An examination of the Degtjareff method for determining soil organic matter, and a proposed modification of the chromic acid titration method. Soil Sci. 1934;37:29-38.

White RE, Peterson RT. A Field Guide to the Beetles of North America (Peterson Field Guide). Mifflin Harcourt: Houghton; 1998. p. 384.

Wills BD, Kim TN, Fox AF, Gratton C, Landis DA. Reducing native ant abundance decreases predation rates in midwestern grasslands. Environ Entomol. 2019:48:1360-8. https://doi.org/10.1093/ee/nvz127.

Zhang W, Ricketts TH, Kremen C, Carney K, Swinton SM. Ecosystem services and dis-services to agriculture. Ecol Econ. 2007;64:253-60. https://doi. org/10.1016/j.ecolecon.2007.02.024

\section{Publisher's Note}

Springer Nature remains neutral with regard to jurisdictional claims in published maps and institutional affiliations.
Ready to submit your research? Choose BMC and benefit from:

- fast, convenient online submission

- thorough peer review by experienced researchers in your field

- rapid publication on acceptance

- support for research data, including large and complex data types

- gold Open Access which fosters wider collaboration and increased citations

- maximum visibility for your research: over $100 \mathrm{M}$ website views per year

At BMC, research is always in progress.

Learn more biomedcentral.com/submissions 